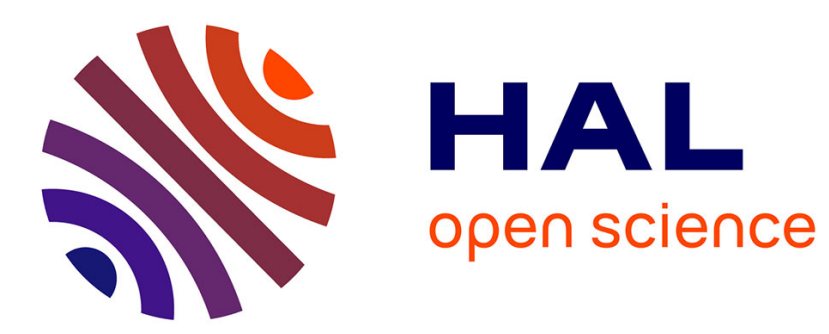

\title{
Place Attachment in Commercial Settings: A Gift Economy Perspective
}

Alain Debenedetti, Harmen Oppewal, Zeynep Arsel

\section{To cite this version:}

Alain Debenedetti, Harmen Oppewal, Zeynep Arsel. Place Attachment in Commercial Settings: A Gift Economy Perspective. Journal of Consumer Research, 2014, 40 (February), pp.904-23. 10.1086/673469 . hal-01137245

\section{HAL Id: hal-01137245 \\ https://hal.science/hal-01137245}

Submitted on 30 Mar 2015

HAL is a multi-disciplinary open access archive for the deposit and dissemination of scientific research documents, whether they are published or not. The documents may come from teaching and research institutions in France or abroad, or from public or private research centers.
L'archive ouverte pluridisciplinaire HAL, est destinée au dépôt et à la diffusion de documents scientifiques de niveau recherche, publiés ou non, émanant des établissements d'enseignement et de recherche français ou étrangers, des laboratoires publics ou privés. 


\section{CHICAGO JOURNALS}

\section{Journal of Consumer Research, Inc.}

Place Attachment in Commercial Settings: A Gift Economy Perspective

Author(s): Alain Debenedetti, Harmen Oppewal, and Zeynep Arsel

Source: Journal of Consumer Research, (-Not available-), p. 000

Published by: The University of Chicago Press

Stable URL: http://www.jstor.org/stable/10.1086/673469

Accessed: $10 / 10 / 2013$ 10:24

Your use of the JSTOR archive indicates your acceptance of the Terms \& Conditions of Use, available at http://www.jstor.org/page/info/about/policies/terms.jsp

JSTOR is a not-for-profit service that helps scholars, researchers, and students discover, use, and build upon a wide range of content in a trusted digital archive. We use information technology and tools to increase productivity and facilitate new forms of scholarship. For more information about JSTOR, please contact support@jstor.org. 


\title{
Place Attachment in Commercial Settings: A Gift Economy Perspective
}

\author{
ALAIN DEBENEDETTI \\ HARMEN OPPEWAL \\ ZEYNEP ARSEL
}

\begin{abstract}
Place attachment is one's strong emotional bond with a specific location. While there are numerous studies on the topic, the literature pays little attention to commercial settings. This is because they are seen as too insipid to rouse attachment. Consumer research, however, suggests otherwise. To address this disparity, the authors investigate how people develop, experience, and act on place attachment in commercial settings. Findings from consumer in-depth interviews and self-reports conducted in France reveal that place attachment develops through perceptions of familiarity, authenticity, and security and evolves into experiences of homeyness. Consumers find these encounters of homeyness extraordinary and respond by engaging in volunteering, over-reciprocation, and ambassadorship toward the place. The authors further theorize these findings through a gift economy perspective and identify a tripartite exchange between the consumer, the proprietor of the place, and selected people from the consumer's social network.
\end{abstract}

\begin{abstract}
This place is at the same time a small restaurant, a grocery, and a café. It symbolizes the life of the village . . . I would be sorry if this place was going to close. . . This place is a kind of extension of our house, with the benefits of a restaurant. In a sense, the owner takes care of us. It is special. It is really the house next door. It is also the place where we had lunch the first Christmas following my father's death. So, it is quite special for me... There has been an accumulation of events that have linked our family to this village and to this restaurant . . .
\end{abstract}

\footnotetext{
Alain Debenedetti (alain.debenedetti@univ-mlv.fr) is assistant professor of marketing at the Université Paris-Est-IRG (Institut de Recherche en Gestion), 5 boulevard Descartes, Champs sur Marne 77454 Marne la Vallée, France. Harmen Oppewal (harmen.oppewal@monash.edu) is professor of marketing at Monash University, 26 Sir John Monash Drive, Caulfield East, VIC 3145, Australia. Zeynep Arsel (zarsel@jmsb.concordia.ca) is associate professor of marketing at John Molson School of Business at Concordia University, 1455 boulevard de Maisonneuve W. Montreal, QC H3G 1M8, Canada. The authors are grateful to Russell Belk, Michael Beverland, Stéphane Debenedetti, Jean-Sébastien Marcoux, Rémi Mencarelli, and Déborah Philippe for their useful feedback on an earlier version of this article, and John Deighton for his support. They also thank the editor, the associate editor, and the three anonymous reviewers for their suggestions and support.

Laura Peracchio served as editor and Soren Askegaard served as associate editor for this article.
}

Electronically published October 9, 2013
It is important for me to introduce it to other people, but only to close friends who participate in the life of our house. (Damien)

$\mathrm{T}$ his vignette illustrates Damien's bond with a specific commercial setting: his local restaurant. While serving as a commercial service provider, the restaurant has become a special place where Damien experiences a sense of homeyness (McCracken 1989). It has become an extension of his home and a treasure that he seeks to share with his special friends. This salient connection arises through an accumulation of personal experiences and domesticized exchanges taking place in, and associated with, the restaurant as a setting. Damien's narrative about the way he is attached to this commercial place points to a central question about consumers and place bonding in contemporary marketplaces: how do consumers develop and experience place attachment in the context of commercial settings?

Social sciences have largely ignored attachment to commercial places, despite a continuing interest in place attachment as a broader topic (Lewicka 2011a). Fried's (1963) seminal work showed how displaced people from Boston's West End grieved for their lost homes. Ever since, a mass of literature has demonstrated that people develop emotional and symbolic bonds with their social and physical environment. Some studies have also shown that people are willing to donate substantial amounts of time, money, or effort to the preservation or protection of the place that they treasure (e.g., Halpenny 2010; Kyle, Absher, and Graefe 2003). So- 
cial science research on place attachment and its numerous correlates mostly focus on two types of place: residential settings (including main, second, and seasonal homes; see, e.g., Jorgensen and Stedman 2006; Mesch and Manor 1998) and outdoor recreation settings such as natural parks and wilderness (e.g., Kyle, Graefe, and Manning 2005; Williams et al. 1992). Researchers have also examined emotionally laden places such as sacred locations (Mazumdar and Mazumdar 1993), workplaces (Milligan 1998), or sports fields (Charleston 2009). Research investigating how people are attached to commercial settings, however, is absent in the broader social science literature. This is possibly because scholars treat commercialized settings as nonplaces (Augé 1995), which, according to Lewicka's (2011a) extensive review of the place attachment literature, may not be capable of triggering attachment.

In contrast, consumer research shows that commercial and commercialized places can very well entail emotional and symbolic meanings. First, research on experiential consumption shows that places can be the stage of extraordinary and collectivized experiences, such as white-water rafting, skydiving, or festivals (Arnould and Price 1993; Celsi, Rose, and Leigh 1993; Kozinets 2002). These experiences are associated with temporary social bonds that go beyond everyday social interactions, but their specific location is typically overlooked (e.g., Celsi et al. 1993) or is peripheral to the experience, as in the Burning Man festival, which moved from Baker Beach, San Francisco, to Black Rock Desert, Nevada (Kozinets 2002). In some cases, the environmental features of the place category are prominent but not tied to a definite location. For example, in Arnould and Price's (1993) study of river rafting as a service experience, participants are looking for and derive satisfaction from an isolated, authentic, natural and wild space, but not from a specific setting. These studies hence emphasize spectacular and nonrecurrent aspects of consumption that provide an escape from everyday life as a temporally limited experience.

Research examining consumer-place bonding within retail and service settings also suggests emotional attachments to commercial places. For example, Maclaran and Brown (2005) investigate how festival malls provide an escape from commercialization and face resistance when they are changed or refurbished. Thompson and Arsel (2004) discuss how consumers bond with localized service institutions against hegemonic brandscapes. Rosenbaum et al. (2007) describe how a lack of social support elsewhere encourages individuals to make connections with, and within, third place servicescape environments. Holbrook (1998) explains how his love for a jazz music store led to a financial sacrifice to support the place. This stream of research hence investigates the meanings and experiences associated with people's bonds with third places. However, when consumer researchers present cases where strong attachments to commercial settings exist, they focus only on the resultant meanings associated with these attachments, not on the ways these attachments are established. Only Maclaran and Brown (2005) discuss utopian place making as an ongoing process. Overall, little attention has been paid, and no theoretical framework has been provided, as to how people develop bonds with commercial settings.

Extending works on consumer-place bonding, we argue that in commercial contexts, place attachment is established through an embedded interactional process that goes beyond commercial norms. Our empirical findings show, first, that commercial place attachment emerges from experiences of familiarity, authenticity and security offered by the commercial setting, and from the associated experience of homeyness. Second, we find that consumers experience this unusually domesticized commercial experience as a gift from the service provider, and reciprocate with supportive behaviors toward the place, in particular volunteering, overreciprocation, and ambassadorship. In identifying this interactional process, we extend the understanding of consumerplace bonding from what constitutes commercial place bonding to how this bonding is shaped and transmitted.

Our article is structured as follows. We begin with a discussion of the existing theories of place attachment and highlight some key unanswered questions, before bridging them to the conceptualization of gift-giving and reciprocity in consumer research. We then proceed to our empirical study, a qualitative inquiry conducted in France. After presenting the findings and how they inform our theoretical framework, we discuss the implications of our work.

\section{THEORETICAL FOUNDATIONS}

\section{Place Attachment in Commercial Settings}

Research on place attachment dates from the early sixties and builds on Fried's (1963) study on forced relocations from Boston's West End. Fried shows that despite having moved to improved residential settings, with better standards of living and higher property values, people grieve for their loss of familiarity and social connectedness. Studies that follow offer a fragmented landscape of divergent perspectives, methodologies, and research traditions (Altman and Low 1992) but define place attachment broadly as an emotional bond between an individual (or a community) and a specific location. This bond is based on an accumulation of physical, social, historical and cultural meanings that become associated with the place through time and experience (e.g., Altman and Low 1992; Giuliani 2003; Scannell and Gifford 2010a; Tuan 1977).

What is particularly striking in this literature is the absence of studies of place attachment in commercial settings. This body of work displays a pervasive focus on residential settings as places with which one can have an enduring emotional bond. This emphasis can be attributed to the home's centrality in an individual's life (Smith 1994). Depicted as "the place of most significance" (Proshansky, Fabian, and Kaminoff 1983, 60), home is considered a key location, a place to live and spend time in, and where memories and affections can emerge through various experiences and encounters. Thus, a sense of attachment has been considered interchangeable with a sense of home, with both

Please use DOI when citing. Page numbers are not final. 
constructs implying an emotional link and sharing of values with the place (Cuba and Hummon 1993). In addition, studies in the social sciences implicitly or explicitly assume that commercial settings are too desolate to sustain attachment (Lewicka 2011a). For example, they depict malls and chain stores as nonplaces (Augé 1995) and as mere "labyrinths of endless similarities" (Relph 1976, 141).

However, while conventional retail environments have been considered as too large, too uniform, too regularly remodeled, and unable to afford a high level of social and psychological interaction (Sherry 1998), managers have increasingly striven to reenchant commercial settings by providing enjoyable, extraordinary, and meaningful experiences and social interaction (Kozinets et al. 2002). More so, strong emotional bonds have been shown to exist for diverse categories of commercial places, such as shopping centers and malls (Maclaran and Brown 2005; Sandikci and Holt 1998), flagship stores (Borghini et al. 2009; Kozinets et al. 2002), brand museums (Hollenbeck, Peters, and Zinkhan 2008), brandfests (McAlexander, Schouten, and Koenig 2002), and theme parks (O'Guinn and Belk 1989). In these works, the marketplace provides a stage for cocreated meanings (Carù and Cova 2007; Sherry 1998) and spectacular experiences.

Whereas these studies provide great insights into servicescapes as a major source of emotion and meaning, the processes through which consumers get attached to their commercial environments has been largely overlooked. Exceptions are Rosenbaum (2006) and Rosenbaum et al. (2007), who show that third places (Oldenburg 1999) can generate strong attachments through the emotional support and companionship they provide to their inhabitants. Research also points out that mundane places that offer no spectacle and no iconic or emotionally salient brand experiences can still be the stage for attachment and lead to ultimate loyalty (Rosenbaum 2006). These studies, however, still do not explain the process through which place attachment evolves. Like most other studies, they only provide insights into how attachment manifests itself.

\section{Manifestations of Place Attachment}

Several studies in the social sciences identify how place attachment manifests itself. First, place attachment fosters personal returns, including well-being (Brown, Perkins, and Brown 2003; Theodori 2001), satisfaction with life (Lewicka 2011b), security (Fried 2000), experience of escaping social or personal pressure (Kyle et al. 2004), and the development of social capital (Mesh and Manor 1998). A related stream of literature discusses instances where people support or protect a treasured place. These occurrences can be grouped into two categories, based on whether they reflect reactive behaviors or more proactive and committed ones. Reactive behaviors include showing resistance toward changes in the place and experiencing grief when the setting is physically or socially modified. Fried (1963), as noted, demonstrates a resistance to relocation; Vorkinn and Riese (2001) and Devine-Wright and Howes (2010) show that landscape changing projects, such as the installation of a hydroelectric plant or a set of wind turbines, lead to very negative attitudes and strong opposition from attached residents. Attached people also resist place substitution. For example, individuals attached to a park declare that they would rather stay home than go elsewhere when their beloved state park or wilderness is temporarily closed (Williams et al. 1992). These forms of resistance to change or substitution express the desire to maintain the connections with the attached place.

Second, place attachment becomes manifest in behaviors that aim to preserve, protect, or advocate a focal place. People who are attached to specific places are willing to protect them (Halpenny 2010; Stedman 2002) through political action (Guest and Lee 1983), civic action (Wakefield et al. 2001), volunteering (Kelly and Hosking 2008), or through environmentally responsible behaviors such as recycling or conserving water (Scannell and Gifford 2010b; Vorkinn and Riese 2001). Attachment to recreational outdoor settings can make people prone to spending money on them, not only to enhance their own experiences but also to improve the environment through education and preservation (Kyle et al. 2003). Indeed, whether they are personal (Brandenburg and Carroll 1995) or financial (Williams et al. 1995), sacrifices for the sake of the place have been suggested as the ultimate manifestation of consumer-place bonding (Shamai 1991). As we will argue, these behaviors are not only manifestations of place attachment but play a role as well in the process that fosters and reinforces the individual-place bond. Preserving, protecting, or advocating the place can be conceived as part of an exchange system through which people build and sustain bonds through reciprocation. We will now explain the motives behind such reciprocating acts. We propose that they emerge from the experience of the place as a unique and special gift that positions the relationship with the place outside the realm of market exchange.

\section{Reciprocation in Servicescapes}

Even though the social science literature does not explicitly theorize supportive behaviors as a form of gift or reciprocation, studies on consumer-place bonding frequently describe behaviors that can be interpreted as reciprocity. Patrons of Rosenbaum et al.'s (2007) suburban diner are attached because they receive emotional support. The diner's proprietors provide or facilitate social interaction and care for their customers as if they were family. Customers in return repeatedly visit the diner and give generous tips. Rosenbaum $(2006,67)$ describes this "ultimate loyalty" as an outcome of attachment. We extend this perspective and propose that such behaviors can be seen as part of a gift system that transcends commercial exchange and in which loyalty serves as reciprocation for the support that is received.

A similar observation can be made for consumers who prefer local coffee houses over their global competitors (Thompson and Arsel 2004). Patrons consider these local coffee shops as "noncommercial environments" (639) and in return declare loyalty and emotional attachment via gift

Please use DOI when citing. Page numbers are not final. 
economy metaphors. Maclaran and Brown (2005) observe a gift economy within a festival mall. What the mall provides - and what "transports Powerscourt to the environs of the gift economy" (317) —is that consumers can see what is behind the scenes. In the Irish designer center, consumers can see the making of jewelry and are encouraged to interact with craft producers. In both studies, however, the authors do not further elaborate on or explain the nature of this gift economy; neither do they dwell on how consumers reciprocate the gifts they receive besides a generalized concept of loyalty. Hence, reciprocation is hinted at, but is not systematically explored.

In Price and Arnould's (1999) study on commercial friendships reciprocity plays a more central role. Customers reciprocate the care they receive from their hairstylists not only with tips or presents but also by getting them groceries, sending them cards, or offering to babysit for them, while also spreading positive word of mouth. Gifts, tangible as well as intangible, are hence part of the exchange. However, consumers are attached to the hairstylist and the service (s)he provides rather than the hair salon itself, which remains a mere background for the person-to-person relationship. Our study broadens this perspective and introduces the place, and the setting it provides, as an anchor for attachment.

The above review shows that reciprocating behaviorswhile present-have not been explicitly theorized in studies on consumer-place bonding and have not been incorporated into place attachment theory. Where reciprocation emerges, it is only alluded to, or is external to the place. As a consequence, the setting itself plays a marginal role in the exchange. We propose that several of the place-related behaviors identified above as manifestations of place attachment, such as personal or financial sacrifices and volunteering behavior, can be understood as gift giving and, more in general, as reciprocating behaviors.

Initial support to our claim comes from Holbrook (1998), who recounts an anecdote showing how an ordinary music store can be the stage of strong emotional meanings and how attached consumers may be willing to support it. In his favorite jazz store he accidentally damages a record. He buys the broken album instead of hiding it, to not betray this retailer's trust (Holbrook 1998). This anecdote suggests that consumers experiencing attachment may feel a moral obligation to support the place and enter into a gift economy. In the following section, we will thus summarize the theories of gift economy, which have been widely studied by anthropologists as early as Malinowski (1922) and Mauss $(1925 / 1967)$ and have more recently been explored by several consumer researchers.

\section{Gift Giving and Reciprocation in Consumer Research}

Gifting relationships are governed more by moral economy logics than by market economy logics (Weinberger and Wallendorf 2012). A gift can be a transformation of "virtually any resource, whether tangible or intangible" through social relationships and giving occasions (Sherry 1983, 160). Gift giving has multiple dimensions (Belk 1979; Sherry 1983). The social dimension is about building and maintaining social relationships. These can be between individuals but may extend to systems of relationships that underlie communities as a whole (Giesler 2006) or to nondyadic exchanges between community members (Weinberger and Wallendorf 2012). The personal dimension is about identity and how the giver and recipient see each other. Donors and recipients may be individuals or groups. The economic dimension is about exchange and whether there is an expectation of returning the gift. This expectation may vary with factors such as age and wealth, and also with cultural context (Joy 2001).

Whereas the gift-giving literature traditionally has focused on dyadic gift giving (Belk 2010), recent work also investigates rhizomatic gift systems, where gift exchange is part of and supports a larger, more complex system of relationships (Giesler 2006). Similarly, Weinberger and Wallendorf (2012) investigate gift-giving relationships embedded in the Mardi Gras festival in New Orleans as an example of intracommunity, instead of interpersonal, gift giving. They identify gift exchanges between anonymous donors and recipients without the presence of a personal (dyadic) relationships or obligation for direct reciprocation. However, as the authors identify, there are subtle reciprocal acts in terms of compliments and admiration given to the gift giver. Another example of complex exchange is the bartering that takes place at the Burning Man festival (Kozinets 2002). Participants who ask other festival goers for food or attend shows are expected to reciprocate, for instance, with a compliment or a joke. In the meantime there is also an exchange between active festival participants and the Burning Man festival itself: when the festival organizers consider a show as valuable, participants receive privileges or status marks.

A gift-giving system can also be built on access and does not have to be limited to an exchange of ownership rights. In Chen's (2009) analysis of the value derived from access to art exhibitions, art visitors only obtain temporary rights to visit and enjoy the artwork on display. Their access to the artwork is transactional when they purchase an entry ticket, but it is also an intangible gift from the art exhibitor that creates a sense of obligation and triggers reciprocating behaviors. Conversely, as found by Bardhi and Eckhardt (2012), not all access generates reciprocation. When access is purely transactional and concerns a product that has only utilitarian value, such as a car-sharing service, there is no evidence of emotional attachment or a moral economy. Place attachment, however, by definition involves an emotional relationship with the focal space. We will now move to our empirical section.

\section{METHOD}

Since our goal was to understand how consumers develop and experience place attachment, we used an interpretive approach. Data collection took place in France and was executed in three stages. The first stage assessed whether

Please use DOI when citing. Page numbers are not final. 
TABLE 1

LIST OF PARTICIPANTS (STAGES 2 AND 3)

\begin{tabular}{|c|c|c|c|c|}
\hline Pseudonym & Age & Gender & Occupation & Focal place \\
\hline Elie & 30 & Male & Engineer & La Cité, concert hall \\
\hline Robert & 34 & Male & Photographer & Le Bon Cru, bar \\
\hline Cécile & 30 & Female & Employed in a sports outlet & Le Transat, bar \\
\hline Samia & 26 & Female & Student & Chez Ariane, restaurant \\
\hline Gilles & 27 & Male & Accountant & Bibliothèque François Mitterrand, public library \\
\hline Pauline & 37 & Female & Works in communications & Le Soleil Gourmand, restaurant \\
\hline Mona & 74 & Female & Retired secretary & Le Printemps, department store \\
\hline Lise & 22 & Female & Student & Au Rêve, bar \\
\hline Jacques & 38 & Male & Serviceman & Parallèles, CD store \\
\hline Pierrick & 21 & Male & Student & Coolin, pub \\
\hline Aurélie & 25 & Female & Works in the French parliament & Aubagne harbor \\
\hline Natalie & 58 & Female & Teacher & Forest, Limousin area \\
\hline Julien & 44 & Male & Project manager & Mercantour, national park \\
\hline René & 62 & Male & Serviceman & Rennes, city \\
\hline Alex & 62 & Male & Owns a travel agency & Paris, city \\
\hline Damien & 55 & Male & Professor & Village Inn and grocery store, Burgundy \\
\hline Célia & 30 & Female & Marketing manager & Théâtre de la Tempête, Theater \\
\hline Jules & 31 & Male & Teacher & Local bar \\
\hline Jacob & 60 & Male & Retired Director of Marketing & Panormo, Village \\
\hline Ali & 39 & Male & Teacher & L'Abondance, wine bar \\
\hline Fred & 37 & Male & Tour organizer & L'Abondance, wine bar \\
\hline Nadia & 32 & Female & Corporate lawyer & L'Abondance, wine bar \\
\hline Annie & 34 & Female & Merchandiser & L'Abondance, wine bar \\
\hline Marc & 41 & Male & Actor & L'Abondance, wine bar \\
\hline Sandra & 34 & Female & Employed by an internet provider & L'Abondance, wine bar \\
\hline Camille & 57 & Female & Therapist & L'Abondance, wine bar \\
\hline François & 52 & Male & Technician & L'Abondance, wine bar \\
\hline Cédric & 38 & Male & Seaman & L'Abondance, wine bar \\
\hline David & 33 & Male & PhD student & L'Abondance, wine bar \\
\hline Patrick & 44 & Male & Works in computers & L'Abondance, wine bar \\
\hline Serge & 31 & Male & Professor & L'Abondance, wine bar \\
\hline Bernard & 33 & Male & Restaurant owner & L'Abondance, wine bar \\
\hline
\end{tabular}

place attachment, as conceptualized in the social sciences, extends beyond the home and outdoor recreation settings to commercial places. The second stage further explored consumer experiences of commercial places they are attached to. This stage included a variety of everyday commercial places such as bars, restaurants, and chain stores, as well as parks, libraries, and theaters. The third stage focused on one particular type of third place, a wine bar that one of the authors was already acquainted with. We will now discuss each stage in more detail.

Stage 1 comprised in-depth interviews with six people and retrospective essays of 500-1,500 words from an additional set of 25 . Participants were recruited through acquaintance, friendship, or kinship, paying particular attention to gender, age, and education variation because the literature indicates that place attachment may differ across these variables (Hidalgo and Hernandez 2001; Rubinstein and Parmelee 1992). Participants were asked to describe their personal experiences with one or more places they love and that are important to them, without any restriction in terms of place type. Consistent with existing literature, this initial information revealed a strong attachment toward residential settings such as apartments or houses. Our participants also listed neighborhood-related places, such as parks and other public spaces connected to private residential set- tings. Finally, they mentioned retail outlets and other servicescapes, including typical third places such as restaurants or bars, thus spontaneously acknowledging commercial places as important centers of attachment.

Stage 2 further explored commercial place attachment through semistructured interviews with 19 participants recruited through a snowballing technique (Tepper 1994). The sample comprised 11 males and 8 females, ranging between 21 and 76 years of age and with varying levels of education (see table 1 for a summary of interviewee profiles). Invitees were asked to submit a list of nonprivate places they love and are important to them. The list not only provided a basis for the interview but also served to screen out participants who referred strictly to private places (e.g., my country house, my grandmother's apartment) or who only referred to general categories of place instead of specific locations (e.g., cinemas, fashion stores). Interviews lasted between 40 minutes and 2 hours. Participants were interviewed either at their homes or in another place of their choice, often a café or a restaurant they liked. The discussion began with a grand-tour question (McCracken 1988): "Could you tell me about the most important place you listed?" Although we used some guidelines to keep track of central themes such as what participants did in the place, their relationships to others, and to the place atmosphere and aesthetics, the

Please use DOI when citing. Page numbers are not final. 
memories related to the place, and behaviors associated to place attachment, the interviewer aimed to be nondirective and let participants tell about the relationship with the focal places in their own way. Emerging constructs like authenticity, familiarity, security, and ambassadorship-which are key to our findings - were never directly mentioned by the interviewer unless prompted by the participants. Data collection continued until interviews produced only minor thematic variations on previous interviews.

Although the interview approach allowed any nonresidential place to be mentioned, bars and restaurants were more frequently mentioned than any other type of setting. This is not surprising given that the literature recognizes bars and restaurants as typical third places. Moreover, given the French study context, these places were even more likely to emerge. While in France mass consumption outlets are widespread like in any developed country, consumer sentiment still strongly favors small business (Filser and Paché 2008) and resists cultural homogenization (Ritzer 1998). For instance, local media recently highlighted the excessive profit orientation in the restaurant industry and denounced the standardization involved in most commercial restaurants (France 2, 2011). At the same time, the French popular and business press frequently feature articles on alternative and independent service providers, like table d'hôtes restaurants that emphasize personalization and social interaction.

Given the prominence of restaurants, stage 3 explored commercial place attachment more in depth by focusing on one particular restaurant, an independent wine bar that one of the authors had regularly visited for many years. Wine bars are a growing phenomenon in France, with 200 establishments in Paris alone. They gather a heterogeneous clientele that is attracted by the conviviality of these spaces as much as by the quality and originality of their offer (IPSOS 2011). Wine bars offer a conviviality that is valued even more than food itself in France (Danesi 2012), where "wine drinking and the café life associated with it" constitute an essential ingredient of culture (Ritzer 1998, 73). Wine bars thus present a rich context for spatial and social interactions (Bildtgård 2010) and are very suitable for this research. The wine bar studied in stage 3 is identified here as L'Abondance. With its bistro tables, lace curtains, old cabaret posters, Laguiole knives, wine cases on the floor, a chalkboard menu, and bread on the counter, L'Abondance offers a quintessentially traditional French atmosphere. It is a popular place that gathers people who, while coming from all walks of life in terms of age, sociocultural background, and ethnic origin, celebrate traditional French food and wine culture.

To assist with data collection L'Abondance's manager allowed us to send an e-mail to all customers in its database, asking for individuals who feel deeply attached to this wine bar and willing to talk about their experiences. This process resulted in 13 interviews, lasting between 30 minutes and 2.5 hours. Interviews took place in the participant's home or in another location of the participant's choice; two were conducted by telephone. Stage 3 interviews started with a broad nondirective question (McCracken 1988) about the consumer's last experience in L'Abondance and then proceeded with more specific but naturally emerging questions, much like in stage 2 .

All interviews were conducted in French and taped. Content analysis was conducted on the original French transcripts aiming to identify the presence, meanings, and relationships of themes within respondents' discourses (Berelson 1952). Thus, we conducted both conceptual and relational analyses, incorporating occurrences of selected themes and proximity of concepts. The analysis was both intratextual (in which a text is read in its entirety to gain a sense of the whole) and intertextual (where the researcher looks for patterns across interviews; Thompson, Locander, and Pollio 1989).

\section{THE COMMERCIAL PLACE ATTACHMENT EXPERIENCE}

Our data suggest that places that consumers feel strongly attached to provide an experience that goes beyond what consumers believe that the market usually offers. This experience comprises a blend of familiarity, authenticity, and security that translates into a broader experience of homeyness. This experience not only arises from the atmosphere and the spatial features of the space but also from the way the proprietors, employees, and other people engage with the place and its inhabitants. The sense of domesticity in the place is highly valued and seen as atypical for a commercial setting and thus is appreciated as a treasured gift. This gift consists of consumers being able to experience the privileges of (1) access to back-stage areas, activities, and stories, thus becoming intimately acquainted with the place; (2) being welcomed in a space where social interaction is dominated by genuineness, spontaneity, sincerity, and personalization; (3) being connected to a supportive place that triggers feelings of trust and well-being.

The gift of access to a homey place in a market setting in turn leads to reciprocating behaviors toward the gift giver. The reciprocation consists of attached consumers demonstrating an enthusiasm and sense of commitment toward the place, as well as an engagement that goes beyond exchange norms. This engagement can happen inside as well as outside the boundaries of the locale and can manifest itself in three ways: First, consumers not only feel at home in the place but also make themselves at home. This occurs through their involvement in back-stage activities that are typically only reserved for staff and unavailable to customers in mundane commercial settings. Second, they support the place through "over-reciprocation" (Schwartz 1967): they tend to give the place more than what would be expected based on the logic of the market in terms of financial means (e.g., they overtip) or in terms of extended relationship exchanges (e.g., they send postcards to the proprietors). Third, they support the place through ambassadorship. Ambassadorship consists of actively recruiting selected members of the consumer's personal network to the place. Before elaborating

Please use DOI when citing. Page numbers are not final. 
on these three behaviors and the exchange process, we will first unpack the nature of the place attachment experience.

\section{The Treasured Experience of Having Access to a Homey Place}

In their most treasured commercial places, our participants experience a blend of familiarity, authenticity, and security that is granted by the place, its proprietors, and its staff. This special blend gives rise to an unusual experience of homeyness (McCracken 1989) and makes the commercial setting unique and very special to the participants.

Familiarity. Our participants treasure specific places because they know them intimately. This in turn facilitates them to incorporate the place into their daily lives, as well as enables them to easily navigate physical and social interactions within its semiprivate dimensions. Being familiar with an object refers to possessing knowledge of its properties and use, as discussed in prior research on consumers' relationship to brands (Zaichkowsky 1985). Etymologically speaking, familiarity also includes a characteristic that is relevant in the case of consumer-place bonding: the Latin word familiaris refers to all who live under the same roof and share everyday life, including close friends or servants. The term thus emphasizes the facilitation of social interactions and the conviviality that emanates from them. As Tuan $(1977,9)$ states, "what begins as undifferentiated space becomes place as we get to know it and endow it with value." This is especially salient for L'Abondance. In this restaurant, the familiarity experience resides in customers' knowledge about not just the place but also about the place's inhabitants. As Nadia illustrates, customers feel integrated because they know the inhabitants' names, professional backgrounds, hobbies, or personal stories:

Do you know the whole story? He [the manager] was working in the movie business and basically has opened this place for his friends. Little by little, he has opened the place to the public. Then his children came and worked here . . . there are very few restaurants where I know the story of the whole family.

Knowledge of the treasured place goes beyond the traditional boundaries of social exchange in servicescapes and includes intimate familiarity with people that manage or work in the place. Knowing the social actors helps create a virtuous circle of social interaction that further enhances familiarity. Camille talks about her passion for cinema, an interest she shares with the owner of L'Abondance. This shared passion was the starting point for further interactions that gradually increased her knowledge about the restaurant and contributed to her feeling of familiarity, which she equates to being at a friend's home rather than in a commercial space. Fred not only spends many evenings at the guests' table in L'Abondance, a special table where the proprietors eat during service hours, but also is involved in outside projects with one of L'Abondance's employees. Compared to commercial friendships (Price and Arnould
1999), which are constrained to commercial roles and spaces, this is a relationship that goes beyond professional boundaries. It is based on mutual interest outside the restaurant, and as such reinforces the attachment with the place.

The intimate knowledge of the commercial setting often goes together with having access to the concealed and the backstage. Ali refers to the presence of a "secret wine list" in L'Abondance, which only a few guests know about, and he can explain the do's (go behind the bar to fetch water pitchers when the place is crowded and staff is too busy) and don'ts (making jokes about Vietnam, as one kitchen employee is Vietnamese). Célia explains that in her favorite place, Le Théatre du Soleil, the audience can see the actors putting on makeup and getting dressed and are allowed to go backstage to see how the scenery and decor are changed. These porous boundaries between the front and back stage distinguish the place from any other and are the reason why Célia does not see plays of this company elsewhere, where there is no such permeability. Likewise, Robert is especially fond of the stories the proprietor of his favorite bar shares with his clients. In all these examples, the place becomes familiar because boundaries between the commercial and private domains become blurred. This familiarity leads to a sense of belonging.

This sense of belonging also manifests itself in participants' experiences of being treated as personal guests in a private setting. Camille feels like she is "having dinner with buddies" when she eats in her favorite restaurant. Marc recalls how he once had a quarrel with L'Abondance's owner but then made up, like friends do. Ali feels welcomed like a friend, or at least as an acquaintance, though he does not consider himself a frequent customer. Robert talks about the "neighborhood life" that characterizes the restaurant where he regularly has his lunch. Julien defines his treasured place, an outdoor food market, as a space that makes him feel like he is in his local village.

This crossing of the boundary between the commercial or public and the family-like or private domains is what many participants depict as making the place an extension of their home. Pauline thinks of her beloved restaurant as a private club where she can not only meet some special friends but also be around strangers who share the same values of conviviality and simplicity. Lise compares going to her favorite café with the experience of a visit to her grandmother's house. She defines the café as "an annex of the house, a house with friends, a kind of shared house" that conveys a convivial atmosphere. This feeling of being invited to a private place intermingles with a sense of conviviality, which can be considered an important aspect of familiarity. Derived from the Latin convivere (living together), conviviality has a positive connotation of the privilege of social acceptance and integration and hence applies to both family members and visitors. As Ali's experience illustrates:

You could be invited to L'Abondance's guest table . . . it only occurred once for me. It was great. I tasted wines I did not order, it was a moment of sharing. . . . I don't remember

Please use DOI when citing. Page numbers are not final. 
all the details but I had the feeling to be included in the "family," although I was an anonymous client. Ok, I was a regular . . . and my face was familiar but no more than that. And I did not ask for more actually. Well, that specific moment at the proprietors' table was for me a mark of friendship. I had the feeling that I was part of something, of being incorporated.

Conviviality is also central for Célia's experiences. For her, going to a play becomes a special experience when she can interact with the actors, who normally remain strangers:

\begin{abstract}
We eat together with the actors and other people we don't know. And we chat even though we don't know each other. And I really like this dimension. What is also amazing is that actors also help with serving guests. It is a unique and very nice way to get closer to the audience. In this theater you are completely immersed in what I call an experience, a complete experience. You are not only here to see a play.
\end{abstract}

In their treasured places, participants know the people but are also known by them. This recognition is not only based on the relationship-building efforts of the staff but also on the desire of the customer to become part of the place. Employees and owners both play a part in building this atmosphere of conviviality and creating a porous boundary between customers and staff: conversations between staff and customers are not just focused on the service or the products and frequently involve personal matters, incorporating consumers into the staff's private spheres and vice versa. The proprietors and staff invite their customers to share something with them, such as a passion for wine, competence in literature, love for design, or simply the story of their lives. For example, Pauline describes the sales people in her favorite bookshop as talent spotters who happily give their opinions about upcoming writers that their customers might like. Except in a few cases, business stays out of conversations, reinforcing the domestic nature of the relationships. In L'Abondance, conviviality is also expressed through domesticized practices: customers that order the same main course at a table are served a large and shared dish, and staff often join friends and/or patrons to eat with them.

Being familiar with a place translates into an ability to easily navigate and interact with the place, which is in stark contrast to an unknown locale. For some, the ease and friendliness of employee interactions is a landmark that helps them feel at home. Pierrick explains that his relationship with waiters in his favorite pub is simply limited to nodding and similar small signs of recognition. But it makes him feel at home. For others, knowing the spatial organization of the place is what matters. Elie knows the dimensions of his favorite concert hall, as well as its architectural details. Gilles feels he has spatially mastered his favorite library. He explains that he feels at home there and could have been its designer. These very specific descriptions reveal that the attached consumer has a great knowledge of the place. This way of acquiring and sharing of secrets about the place is important for the maintenance of identity and individuality (Korosec-Serfaty 1984). Spatial knowledge is often also connected to a desire to mentally, and sometimes physically, appropriate the place because for customers, $m y$ place also means the place where I belong. Additionally, the desire for mental appropriation explains the frequent occurrence of terms like "my," "ours," and "at home" to describe those spaces in our interviews.

The desire to spatially appropriate the place also explains the recurrence of stories about consumers' rituals within the space. Robert reveals that he always puts his helmet in a small messy area on the right side of Le Bon Cru bar and feels compelled to say a loud "good day, gentlemen" each time he enters the place. Rituals can be embedded in strategies for gaining privilege and advantage over ordinary consumers, such as Jacques's strategy at Parallèles CD store: When he considers purchasing a $\mathrm{CD}$, he always first hides it in a specific location in the store, or uses his bag to conceal it, so that he will not miss out on bargains while looking at other CDs. This act is only possible because he is at ease with the general spatial environment of the store. Likewise, Patrick summarizes this mental and spatial appropriation as follows:

I was very lucky because I had a 200 square meter flat in Paris: my 25 square meter studio apartment is just on the other side of the street, and my dining room, my kitchen, and my living room for having my friends over are at L'Abondance . . . it is as if I am home. I would feel weird to wear a shirt and a tie at L'Abondance. It is a bit like I belong to the place. You know, like I have my own napkin ring over there.

Knowledge of a place allows consumers to adopt these recurrent and domesticized behaviors and carry them through with a sense of familiarity, because they have been given the opportunity. Our participants have appropriated offstage, private, and intimate details of a commercial place from attic to cellar, thus actively receiving a sense of a familiarity that is beyond the commercial offering and is frequently compared to what they feel for their homes. This experience is enhanced by their familiarity with the spaces' inhabitants and translates into feelings of conviviality.

Authenticity. Participants consider treasured commercial places as authentic, in the sense that the place is genuine (Beverland and Farrelly 2010), irreplaceable (Grayson and Martinec 2004), and not limited to commercial intent (Holt 2002). In the context of postmodern marketplaces, authenticity is perceived and constructed, rather than being an objective characteristic of goods or experiences (Grayson and Martinec 2004). In treasured commercial places, this perception is formed through the people in the place, the activities these people perform, and the place's physical appearance. The inhabitants of the place provide customers an authentic experience. Proprietors, staff, recurrent customers, even suppliers are identified by participants as core elements of the setting. All these people are extended representations of the place because they interact with customers, thus building social markers that constitute the spatial

Please use DOI when citing. Page numbers are not final. 
environment. The furniture, the decorations, and the activities provided in the service setting all reinforce this perception of authenticity. A set of unique, irreplaceable, and genuine experiences leads participants to go beyond marketplace characteristics of the setting and experience its home-related cues.

Consumer experiences of authenticity are first established by the absence, or decreased presence, of commercial cues in the treasured setting:

It was a decor you could find in the mountains, in Savoie. There were a lot of old objects that gave the place a rural flavor, also probably linked to the memories these objects carried . . . there were landscape paintings, not what you usually see in this neighborhood's restaurants. There was a rustic aspect that I associate with home. Even an atmosphere that you can find in the mountains, in winter time, when you sit around a table with friends, to eat cheese fondue. This was the spirit that had been created in the place. (Sandra)

Commercial aspects are mostly absent in respondents' discourses. Respondents do not reject the idea of being seen as consumers and being part of a commercial exchange, but in describing attachment, they refer to the ability of places to offer more than a set of products or services. For example, Robert insists on the predominance of what he described as a human link, a simple and nice bond, as opposed to a merely transactional relationship where "you only are a guy with a credit card." Elie refers to his favorite concert hall as an important stage for political and social debates. Damien presents his hometown inn as a place with a "specific mode of consumption," where the proprietor is more like a neighbor with a shared history than just a cook in a small village restaurant.

Participants' expressions of their relationships with their treasured places indicate a contrast between inauthentic and authentic commercial places, in that the authentic ones have a life outside the commercial realm and do not strictly follow laws of supply and demand. Robert describes a trendy fashion shop as a "completely fake place, where bullshit products are sold at amazing prices" when he compares it to the small and simple next-door restaurant he is attached to. Nadia describes the restaurant that replaced her favorite one as "full of goodwill" but unable to present more than a façade. Commercial places can fail at being special because they appear to their customers to be strictly transactional, unable to diverge even slightly from their business routines and unable to share something meaningful with their customers. Treasured commercial places, on the other hand, offer a genuinely homey experience:

Daily specials were home made, and you feel they were doing this for the fun of it . . . not like in a restaurant that has to make profit. You felt like you were in somebody's home. No pressure on anything, and especially not on consumption . . . you felt like these people, these owners, were happy, happy to welcome other people . . . I was about to say, happy to welcome people at home. I mean, they also looked like having a pleasant evening. Whereas in other places, you felt more or less that it is a business, a real restaurant . . . you felt they really put their expertise in it . . . it looked like more "real" than in other places. (Serge)

As Serge's description shows, consumers experience commercial places as authentic when they can enjoy the main activity provided by the place (enjoying good food, seeing an excellent play, appreciating music and CDs) while the business-related aspects stay in the background. Relationships with the proprietors are perceived as genuine and go beyond what customers typically expect from a commercial place. The social encounters are experienced as spontaneous and not primarily driven by commercial motives. Marc reports that the welcome in L'Abondance reflects "a true generosity," because customers are greeted with straightforwardness and simplicity and without any bias against their age or looks. Social connections are informal and disconnected from typical commercial norms: customers' frequency of patronage is not acknowledged through economic incentives or extras but through marks of friendship and respect. Robert explains that in his favorite restaurant, waiters do not offer free drinks to regulars but frequently inquire about their professional lives. Beyond merely offering a kind welcome, employees and managers behave openly and genuinely, with no inclination to emphasize their strengths or hide their weaknesses or opinions. As Annie notes, L'Abondance is authentic because the owner is sometimes "grumpy" and can refuse service to customers. As a result, she considers the people working in this place as "not servile." Participants perceive their treasured commercial places as unique due to this spontaneity and openness of its managers and employees. This uniqueness is further enhanced by the way in which commercial activities are performed:

Let me speak about something amazing and unique, something that you cannot find in any other place in the world. On Saturdays and Sundays, a guy from an oyster farm of Arcachon or Cap Ferret comes and directly sells its oysters in the bar. He sells them and opens them on the spot. Right there on the front door . . . and you know, customers stand on the sidewalk, sit on the hoods of the parked cars, even on the garbage cans! So you buy one bottle of white wine and sit outside, relaxed, eating your oyster. And that, man, is unique! (Robert)

The furniture, decoration, and architecture of the place convey authenticity when the materials and objects show the managers' or employees' personal touch and tell a story. Robert suggests that the wooden floor in his favorite restaurant reveals the manager's tastes and at the same time is organic and not "industrially processed." Gilles considers the François Mitterrand contemporary library to be authentic because to him its architecture represents the true and living Paris rather than the touristy Paris, which looks like "a film set."

Reflecting personal taste is more significant than subscribing to established servicescape aesthetic norms, which is why Cécile finds it important that her local bar has the owners' personal furniture. The ability of the place to tell

Please use DOI when citing. Page numbers are not final. 
an authentic story is crucial and contrasts with sophisticated merchandising, which is perceived as not only unnecessary but also sometimes unfavorable. Sandra points out that a "chair designed by Starck is not always a bonus." Fred likes the unpretentious furniture of L'Abondance because "the eyes [of the customer] should not be distracted by the decoration and the design." Such simple and personalized spatial settings tend to make the place unique and homey. For example, all participants who treasure L'Abondance mention the still-working fireplace. To them, it symbolizes the hearth of the home, reminds them of memories or fantasies, and is perceived as something that is unique in Paris. Lise elaborates on the homey and decommercialized aesthetic of her local coffee shop. Its aesthetic alters the experience of being in a public space and imbues the space with homeyness:

The place is so tacky that you feel like being in this woman's home. You know, it is decorated with awful paintings, but I like it. There are also some pictures, you know, some pictures of her when she was younger.

In conclusion, the authenticity perceived in treasured commercial places is based on exchanges that go beyond mere commercial aspects. It is based on spontaneous social interactions with familiar individuals (instead of anonymous staff) and a personalized service setting that conveys homeyness. Although being business operators, proprietors invite the consumer to engage in activities that are not undertaken purely for profit but rather because the provider intrinsically enjoys the activity. Indeed, through their behaviors and the setting they provide, the proprietor and staff, as hosts, offer the customer an opportunity to engage in a different type of exchange, one that is not primarily transactional but that consists of a system of mutual appreciation and engagement. As such, the place provides an experiential context that consumers can mobilize to coproduce an experience of authenticity and homeyness (Carù and Cova 2007).

Security. Our participants frequently refer to their treasured places as safe havens that provide comfort, support, and shelter. These are characteristics central to the experience of home (Bachelard 1964; McCracken 1989; Tuan 1977). In our data, the experience of security involves the place's ability to provide a physical, social, and symbolic shelter from the outside world, via the care and support generated by the social environment, while also offering a place where social norms are perceived as less constraining than in conventional commercial settings.

Consumers experience treasured places as shelters because these places protect them from the social aggression and intrusion they attribute to commercial settings. They feel secure in a place where they believe they are among people similar to themselves, rather than with just anyone, like Cécile who feels like being "in [her] world, in a sort of family" to explain how she appreciates being "with sailors" in her favorite bar, where she usually goes after sailing. They do not fear the intrusion of employees and/or managers, because social interaction with them is framed as supportive and friendly rather than based on monetary interests. Pauline mentions that one of the best moments in her favorite restaurant is when the manager comes to her table to chat a little. She also describes her favorite bookshop as "a haven" where other consumers share her values, which is comforting and reassuring. In L'Abondance, senior staff plays the role of godfathers. They greet customers as they would welcome young relatives, taking them under their wings and offering them protection:

\begin{abstract}
When the owner opens the door and welcomes you, well, you drop your guard. Because you think: it is nice here. They had the ability to make you feel relaxed, as soon as they say their first "hello." I was relaxed because it was like a high mountain refuge but also a symbolic refuge. For me, it was a shelter. In the noise, the chaos, or the hustle of everyday life, there was L'Abondance. (Patrick)
\end{abstract}

As Patrick mentions, his treasured place allows him to be free from worry, as the staff is trustworthy and treats him with a familiarity reserved to relatives. Other participants see the owner as an uncle, a grandfather, or even sometimes as a "patriarch" under whose roof one can feel secure.

Our data also show that participants feel secure because they feel like they don't have to conform to the constraining social norms of traditional service encounters. They "don't have to play a role," as Cécile puts it. In her favorite bar, she does not hesitate to take off her sailing boots and socks when she sits down, as if she were at home. She indicates that the experience of security is a subtle mix of absence of social judgment (no dress code prevails) and ease of interacting with the other patrons. Jacques defines his most treasured places as settings that afford him relief and help him recharge his batteries and, at key moments, have been a refuge. Robert feels sheltered in his favorite bar, explaining that it is "the kind of place, when you do not feel very well, when you are in low spirits, where you feel protected. It's your home, if you see what I mean."

The features of the space itself enhance this feeling of being protected in a family-like environment. The spatial environment provides security through physical protection against the outside world, for example, through the roof, the walls, and the curtains. Participants depict L'Abondance as separated from the outside world. Its door is like a gate and is always locked, and customers have to ring the bell to get in, symbolizing both protection from the outside as well as mimicking the characteristic of a home front door. They mention the velvet curtains that cover the restaurant windows, which prevent them from being spied upon from the street. Once they are in, they are in a place where they feel protected. Participants associate L'Abondance with smells reflecting family cooking or with the presence of a fireplace. As Fred indicates, treasured places provide "a primitive feeling" of being secure.

Essential to the feeling of security is also the ability of the place to offer symbolic protection against the uncertainties of the market. Attached customers feel protected from the intrusion of market-related risks, such as unex-

Please use DOI when citing. Page numbers are not final. 
pected high prices, disappointing service, or low-quality products, not only because they perceive the place as detached from the usual market rules but also because the place's commercial rules are transparent and identical for all customers. When describing a luxury grocery store he patronized for a long time, Robert stresses that staff "considers you as a client but also as a human being. You are not differentiated on the basis of dough." Similarly, Fred explains that in L'Abondance, he "does not have to look at prices" because he knows he is not "going to be ripped off." Ali notes:

When the owner told me how prices were calculated for wine bottles, I understood that this place was really different. Well, they buy a bottle for a certain amount, and then they add 5 Euros on the price they have paid. Isn't it amazing?

Customers perceive their treasured commercial places as safe havens against the cold logic of the market. Pauline treasures her local bookshop because employees claim they defend unknown editors and unknown writers against blockbusters. Célia's attachment to Le Théâtre de la Tempête rests partly on its director's policy of low prices, which allows for social diversity in the audience. Fred explains that L'Abondance does not have conventional bills but relies on an honor system. At the end of the meal, customers are simply asked what they have eaten. Thus he considers that "the place does not follow the procedure of a usual restaurant." In all these examples, participants perceive their treasured places as transcending the logic of the market (transparent pricing, protection of small suppliers against large firms, promotion of social diversity through low prices, etc.) and thus as homelike.

Knowing that the owner sets low margins to help you discover wine, that is gratifying, I mean, as a consumer. Well, you know, paying 30 Euros a bottle that is worth 8 in a wine store . . here you pay 12 or 15 . . . so you could feel as a guest. You are invited to discover. You are not going to get fleeced. (Annie)

These experiences suggest that consumers feel like they are guests who are protected against malignant side of the market. In a sense, the proprietors of treasured places give consumers the assurance of both providing access to the market and of being protected from it. Hence, they offer a comfortable haven. They allow consumers to feel safe from other people (e.g., intrusive employees), from the physical environment (e.g., overwhelming noises or crowds), and from the market (e.g., the risk of being ripped off). Treasured places are also perceived as market filters where the laws of supply and demand are put aside if they contradict the homey spirit of the place, as explained by Jacques:

I am not naive and I know that there has to be a market for music, that people that play music have to earn money, that there are people that burn CDs . . . but for me, FNAC [France's leading retailer for music goods] is an awful supermarket with displays promoting one month the new Lara Fabian and next month the new live [album] from the Rolling Stones . . . at Parallèles, this is not the same. All the CDs are secondhand and put on the same level. I like the nonmarket atmosphere of the place. Yes, I like it. It is not expensive. It is obvious that people who work here do not try to overprice a CD just because it is a collector's item.

In sum, the experience of being familiar with an authentic and secure place is the cradle of the place attachment experience and leads to experiences of homeyness. Proprietors, and more generally, those who regularly interact with customers, play a major role in providing this feeling. Consumers feel privileged to have knowledge of, and access to, their treasured commercial places. However, their feeling of being privileged does not arise from comparisons with other customers of the treasured place; instead it resides in them being able to patronize a place that gives them what commercial places typically cannot or do not provide. This explains why customers interpret the place and the homeyness they experience as a treasure and a gift. We will now discuss how consumers reciprocate through actions inside and outside the place.

\section{Giving Back to the Treasured Commercial Place}

The combination of familiarity, authenticity, and security, and the experience of homeyness emerging from it, is so unusual and exceptional in a commercial setting that it is experienced as a gift and hence gives rise to a gift economy. This gift is reciprocated in three ways: The first type of reciprocation is volunteering for semidomestic activities that go beyond what is expected under commercial norms. As consumers feel like being part of a domestic space, they start actively engaging in helping behaviors as they would in a friend's home. This reciprocity resembles the interaction between consumers and their guides as observed by Price, Arnould, and Tierney $(1995,94)$ in their study of extended river-rafting trips, where clients demonstrated a wish to "give something other than money back to the guides (e.g., advice, job offers, invitations)." In our case, the reciprocity arises when attached consumers display volunteering behaviors to show proprietors that they appreciate the presence of the treasured place and being granted access to it. The second way of returning consists of over-reciprocation, which is providing compensation that goes beyond commercial norms (Schwartz 1967), as in excessive tipping or demonstrating price insensitivity. Third, consumers engage in ambassadorship. Unlike volunteering, which is typically performed on site, ambassadorship happens outside the focal place and beyond the service encounter's temporal limits. Ambassadorship is not only a way for attached consumers to reciprocate the gift of homeyness to the proprietors but also a means of gifting it to other people, albeit only specifically selected ones, by providing them access to the treasured place. Now we further elaborate on these three acts of reciprocation.

Volunteering. Volunteering is rooted in reciprocity as enacted in the domestic realm and can consist of participants being eager to help and participate on the spot. This is

Please use DOI when citing. Page numbers are not final. 
particularly possible in commercial settings where there is extended contact, such as a restaurant or a bar. For example, Patrick remembers a customer who always came from the countryside to L'Abondance with products from Ardèche and once brought a herb pie that he shared with the staff and other customers. This mode of reciprocation is often linked to the degree of familiarity the consumer has with the place. As in a friend's home, the more knowledgeable one is about the space, the easier it is to see what can be done to help and how. Similarly, in our data, knowing about the back stage is often accompanied by a willingness to participate in backstage activities. David tells how he spent a late evening with the manager of L'Abondance, drinking wine while washing the dishes after the bar had closed. In treasured homey settings, such participation occurs naturally and spontaneously:

It is ok for me to stand up and go to the kitchen to say "I need this" or "could you give me some bread?" You don't do this in a restaurant, but there [at L'Abondance] it's like home, like at a friend's place. This is the spirit that Eugène [L'Abondance's proprietor] has established; well, it's the freedom he gives us that allows this kind of familiarity. (Camille)

This participation blurs the boundaries between the consumers and staff and the ascribed roles of the two as in more conventional service encounters. Consumers and staff take on each other's role and share their experiences, as an act of sharing in (Belk 2010). Such acts of sharing enhance familiarity and foster attachment, as in L'Abondance, where the staff dines in the restaurant alongside the customers, even sometimes asking customers to join their table.

Over-reciprocation. This involves supporting the place far beyond that what is commercially expected (e.g., Price and Arnould 1999; Rosenbaum et al. 2007) and can occur within or outside the treasured location. Nadia gives huge tips, even though tipping is not customary or required in France, because she believes l'Abondance deserves to be rewarded. She says, she "gave money so the place continues to exist." Reciprocation can also occur as an intention or a willingness to help via less domestic and more market based acts, especially if the existence of the commercial place is threatened. Célia and Robert speak about their willingness to pay extra for the same service or products in order to support their treasured place. Damien would be willing to spend time distributing leaflets on the street to support his local movie theater. Fred also gives financial support to his treasured place, but his support is through indirect means, such as by not switching to lower priced options:

I organized a party at Versailles last year for Japanese people. I bought a lot of products from Eugène. I ordered salmon, comté cheese, and also some wine from his suppliers. And I showed Japanese people these products that L'Abondance had introduced me to. So, I did a wine and cheese party in Versailles with Japanese people. It was awesome. Well, there were other products, too; otherwise it would have been too restricted. I know some other wine and delicatessen produc- ers, but I went to Eugène to buy part of what I needed. It was more expensive than directly going to his suppliers, but it was also a favor that I wanted to do for him, given all that he previously had shown to us. I wanted to help him financially too. Well, I think this is important to reveal to others what has been revealed to you.

Support and help are not the sole marks of over-reciprocation toward the treasured place. Participants' reports also reveal how extended social exchange with proprietors is at the heart of the place attachment experience. Robert used to send postcards to his favorite local restaurant when he was out of town, as people do to their family or close friends. Ali once sent an e-mail to L'Abondance's proprietor to thank him for the nice evenings spent in the restaurant. Camille refers to the appreciation and loyalty as ways of reciprocating the generosity of the proprietor, whom she perceives as someone that doesn't even expect to receive a countergift:

He was giving without waiting for something. That is why we gave him too. He gave without waiting . . . you did not have to pay for what he was giving. It was sincere. It was out of his guts, he was sharing his passion. And so, we received this, and we gave differently, for instance by being loyal, by chatting with him, by appreciating his products. I think we gave back this way.

In many cases, countergifting is framed as home-based, instead of market-based reciprocation. Patrick recalls how he told L'Abondance's proprietor reacted when he told him that the wine bar was his second home: "he smiled, and he said to me: you cannot imagine how happy you make me. And we had a drink. I remember that moment very well." Correspondingly, the participants' perceptions of the exchange alter as it transforms from a commercial into a moral exchange, as explained by Ali, who says: "Here, you don't buy anything. You've been given things, and you give something to the proprietor at the end." Marc agrees: "This is not a place where you come, you eat, you pay." These examples show that consumers experience the exchange process as different from a mere commercial exchange. Moreover, the immediate and bounded reciprocation that takes place in typical commercial transactions is replaced by a desire for suspended reciprocation as in ambassadorship.

Ambassadorship. When consumers are attached to a specific commercial place, they also tend to take on a role as guide and advocate for the place. This role allows them to not only reciprocate the gift of access to the place's proprietor, by recruiting new customers, but also allows them to share the treasured place with people of their choice. Based on our empirical findings, we distinguish two aspects of ambassadorship: selective matchmaking and transmission. Selective matchmaking consists of consumers bringing deliberately chosen friends and relatives to the place they love. For example, Elie always asks his friends from Brittany to meet in his favorite concert hall in Rennes. Robert and Sandra take their friends to their treasured hangout place.

Please use DOI when citing. Page numbers are not final. 
Mona regularly takes her grandchildren to her beloved Louvre. Fred and Serge both have brought relatives to L'Abondance.

Consumers only play the role of ambassador with people that matter to them, such as close friends, parents, or some business relationships. The selection is based on the qualities of the invitees, but is not necessarily limited to a specific number of people. Compared to traditional word of mouth, ambassadorship is more selective but also more persistent, because the ambassador wants to ensure that the place has really been visited by his or her targets. That is why consumers select specific people they see fit well with the place among their friends, relatives, or business contacts, as illustrated by Jacques:

This place is for people like me, who adore spending hours searching for specific CDs. That's why I brought my fellow DJs . . . it is reserved for the initiated people. I can recommend it to anyone, but, when it is about getting there with someone, I know that I am going to spend a lot of time, and that I'm going for CDs specifically. So, I really have to go with someone who has a passion for music.

Participants select people who fit with the setting but are also clear about those who do not fit. Camille states that she would never take some of her relatives to L'Abondance, and David says it would not occur to him to bring some of his friends to the restaurant. Like David, Cécile asserts that she would never even consider people who do not fit with her treasured place; or if the fit is not obvious, she prepares or grooms her associates for the right fit by ensuring invitees are in the right mood or by creating the right expectations:

I like to bring people in but usually people who are not sailors do not feel comfortable in it. This is another world that they don't know about . . . well, I like to take buddies there . . . but only after I give them a sailing class. After that, it's easier to take them to this bar than to have dinner with them at home.

Attached consumers not only want the commercial setting to be appreciated, they also want it to be frequented. Indeed, beyond taking pleasure in inviting friends and relatives and getting them to discover the place, consumers consider ambassadorship a moral duty. For example, Robert explains that it is "compulsory" to bring people to Le Bon Cru bar, because that is a way to protect this "unique" place from the uncertainties of the market.

Transmission of place attachment is the second aspect of ambassadorship. Attached consumers make the place a heritage that passes to selected people on their networks. Typically, the discovery of the place does not happen by chance; often a relative or friend introduces participants to the place. Most participants from L'Abondance had been first brought there by a friend. When access was obtained through a networked other, place attachment seems to be stronger as existing social ties strengthen the bonds formed with the place:

You see, there is some kind of tradition in that kind of place. To my mind there is a transmission going on. Not like from father to son, but in some kind of emotional way . . . when I first came, I said: wow! And thanks to the person who brought me in . . . he was the person I talked about and who used to go with his father when he was a kid. (Robert)

This example also shows the genealogy of place attachment. Consumers carefully select which person to introduce among their close contacts and hope the bond will be perpetuated through time, almost like an inalienable cherished possession (Price, Arnould, and Curasi 2000). They experience the opportunity to pass on such a gift to members of their close network as a privilege. Pauline describes her relationships with a Parisian restaurant and a department store. For both, she feels like a member of the club of those who are in the know. She acknowledges that not just everyone is being introduced to these places and that they are not fully or easily accessible to all. As Annie says, "You have to be initiated, invited, or brought in by guides. There is an initiatory dimension in L'Abondance," and thus she feels a sense of duty to pay forward and bring other people to the place. The same applies for Camille:

[My assistant] told me: "I have to bring you to a great restaurant you're gonna love" . . . it was like love at first sight, so I went back there a few times, and I said to myself: "I will bring my son and his girlfriend to the place." . . . I brought important clients who are used to going to La Tour d'Argent . . . all the people whom I brought there now regularly go there on their own. . . . Once, when I went there with a friend and entered the place, I found my son and some of his buddies there.

Participants are proud when they bring someone who fits with the place, because it is not just a simple gesture; rather it is a challenge. Their own satisfaction depends on the perceived pleasure of their companions. What is important for Robert is that his friends' eyes were shining with joy when he brought them to Le Baron Rouge. Bringing people to his favorite library is a pleasure for Gilles because he likes the idea of sharing what he considers a hidden place: without him, the place cannot be easily found. Nadia explains that bringing people to L'Abondance is a sign of friendship, and Cédric expresses satisfaction in seeing his brother amazed by this place. Thus, ambassadorship helps to sustain and reinforce the relationship between the place and the attached consumer, as well as the bonds between the focal consumer and her or his close associates. The introduction of friends or other acquaintances to the place acts like an initiation, with the attached consumer taking the role of the elder who guides and coaches the invitees into becoming one of the initiated. The result is a strong and interconnected base of committed customers for whom the place is likely to become very important and part of a shared experience. Yet, this shared experience has a flipside. When a companion alters the shared experience by being displeased by the place, ambassadors can be unsatisfied, or even vexed:

I brought someone who really did not like the place. She is

Please use DOI when citing. Page numbers are not final. 
my cousin. She found it weird, which shows that you should never bring someone from your family. She told me: I don't see why you like this place. Well, you don't choose your family. (Patrick)

Treasured commercial places are repositories for consumers' values and self-expression, and consumers are only fully satisfied when their companion is able to share their appreciation for the place. As ambassadors, consumers express their attachment by facilitating access to those who are considered able to develop an emotional bond with the place. Annie underlines a "fit," Gilles uses the metaphor of a mirror of the self, and Nadia talks about a place she is aspiring to be like. The gift of access to a new place also helps deepen the bond with the invitees, because the ambassadors reveal something personal about themselves to their invitees. Thus, treasured places crystallize consumers' self-reflections: successful ambassadorship reinforces and socially confirms their selection and appreciation of the place, and concurrently their selves, as special. Figure 1 summarizes the social exchanges that occur between the focal consumer, the proprietors, and the invitees in the place attachment experience.

\section{DISCUSSION AND FUTURE DIRECTIONS}

Our study finds that consumer attachment to commercial settings is based on a complex social exchange process between proprietors, attached consumers, and their invitees. We find that as consumers become attached to a commercial setting, they interpret their experiences with the place through frames originating from the private and domestic realms. As a result, the commercial and transaction-related characteristics and benefits become peripheral to the homey and nonmarket characteristics of the setting. Sharing in (Belk 2010) and gift giving (Sherry 1983) become the principal frames in the consumer's (emic) interpretation of the place experience, and the place attachment experience becomes part of a wider social exchange process and moral economy. Our study shows that this exchange process results in attached consumers desiring to support the place through volunteering and other forms of reciprocation. One particularly salient form is ambassadorship. Consumers spontaneously serve as a guide and advocate for the commercial setting, thereby extending the exchange process to selected members of their wider personal networks.

\section{Unpacking Homeyness and Attachment in the Marketplace}

The emergence of homeyness in commercial settings illustrates the liminality between the market and the domestic worlds (Boltanski and Thévenot 2006; Cova and Rémy 2007) and between market and moral economies (Weinberger and Wallendorf 2012). In our study, the experience of home is based on intangible features and situational interactions rather than on the presence of personal possessions as in the case of studies on the mobile concept of home (Bardhi

\section{FIGURE 1}

PLACE ATTACHMENT AS AN EMBEDDED GIFT EXCHANGE

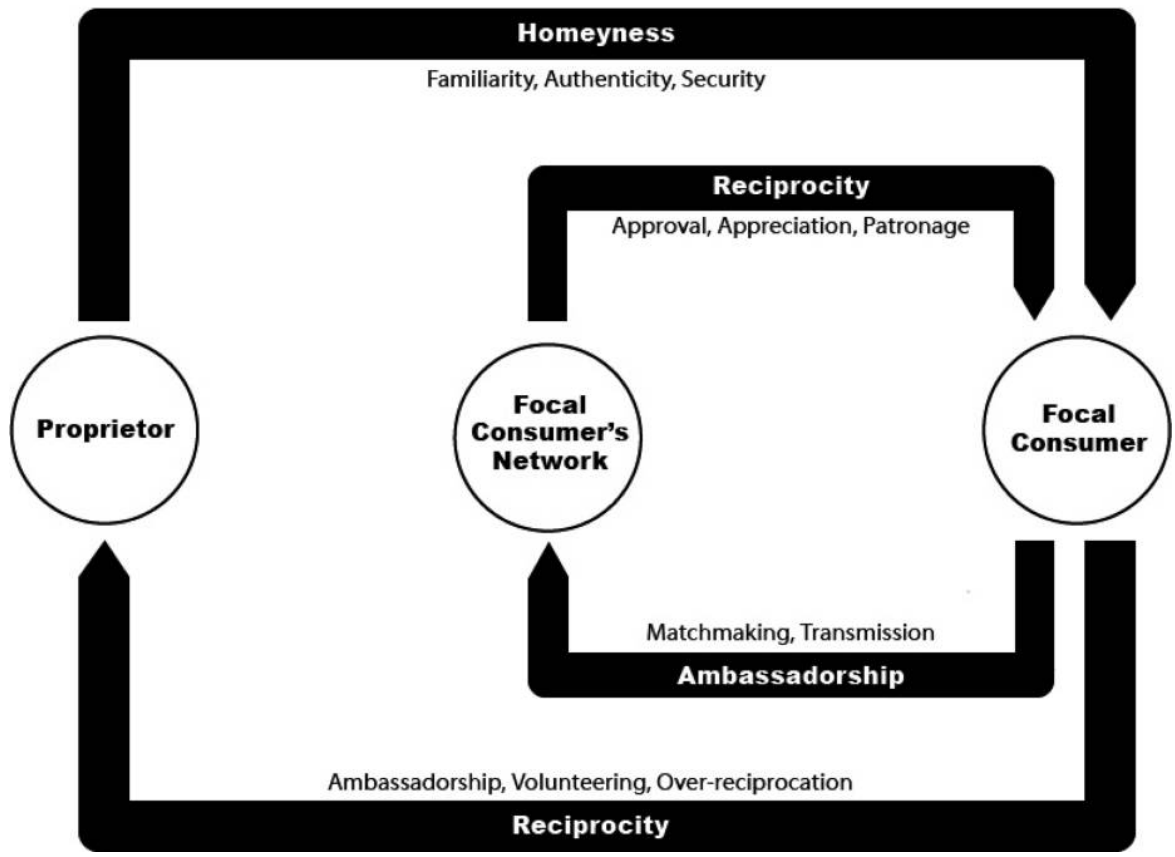

Please use DOI when citing. Page numbers are not final. 
and Arnould 2006) and acculturation (Mehta and Belk 1991). Rather than singularizing the space and instilling it with special possessions, our participants respond to domestic cues in the treasured commercial setting. This resembles the work of Bardhi, Eckhardt, and Arnould (2012) who show that global nomads develop a sense of home through situational attachment to possessions and practices rather than a solid and singularized relationship. Thus, our research contributes to the understanding of materiality of space by showing that person-space connections can be created through a set of situational relationships. Our participants feel at home because they experience the place as familiar, authentic, and secure through their interactions with a particular set of spatial and symbolic elements. For example, the closed door and the bell in L'Abondance allow the proprietor to welcome and say goodbye to every customer individually, as is customary in the domestic interactions that take place in private settings. Further research could examine how consumers manage the boundaries between the commercial and the domestic (Cova and Rémy 2007) and how they make sense of these boundaries through time. From the perspective of the managers it is also important to investigate how proprietors could manage these boundaries to foster domesticized meanings that emerge from boundary crossing, such as lingering, while keeping control of the space and service. As these boundaries are also contingent on the type of place, a related question involves how different categories of spaces generate their own norms of boundary crossing and how consumers can be inducted to adopt these idiosyncratic norms: for example, lingering at a coffee shop might be perfectly acceptable while not in a faster paced environment. At the same time, managers have to realize that consumers are not passive adopters and will, in their own way, interpret and respond to attempts to manage the place and create norms. This is a manifestation of interagency (Kozinets et al. 2004; Sherry, Kozinets, and Borghini 2007), a process of coproduction in which consumers and producers successively take control and surrender in the creation of products and experiences.

In third places, informal social interaction plays a significant role (Oldenburg 1999). Rosenbaum et al. (2007) suggest that third places are a major source of attachment for people who otherwise lack social connections in domestic settings; hence they are a substitute for home, whereas social actors in the setting serve as the surrogate for a family. Our research extends this perspective by showing that a need for social bonding is not a precondition for attachment but is rather one context where attachment is sought; consumers that are socially well connected can still develop attachment to a particular place. We also show that attachment is not limited to particular third places such as diners and may well extend to other types of commercial places, including bookshops, concert halls, restaurants, bars, music stores, and grocery and department stores. A topic for future study is to what extent place attachment can exist and can be sustained outside of a social context and related exchanges.

Issues for future research furthermore include the spatial and temporal dimensions of place attachment. Regarding spatiality, the case of L'Abondance shows that place meanings are often embedded. L'Abondance represents a repository of meaning associations with the fields of La Chapelle d'Abondance in the Savoie, which is the home region of its proprietor and where most of his food suppliers are based. As such, L'Abondance provides a convergence of interrelated homey cues that contribute to its domesticized meaning. Further research could investigate how a broader set of networked places and their associated meanings permeate and contribute to one's attachment to a focal place. Regarding temporality, researchers could examine how homerelated feelings can be duplicated or replicated in the case of chains, expansions, or relocations. As we identify the situational nature of the relationships that generate attachment, understanding how these relationships may be transferred and how new experiences can be cocreated is an important quest for researchers and practitioners (Sherry et al. 2007).

Our findings are consistent with McCracken's exploration of homeyness in the context of Canadian homes and the "place attachment characteristics of the home environment" (1989, 169). But although several of McCracken's properties of homeyness overlap with our findings, in McCracken's ethnographic account, homeyness marks the differentiation between the private life and the public life. In contrast, our research shows that homeyness can reside outside domestic settings and can very well be experienced in commercial places. This is in accordance with Noschis (1984), who demonstrates that extensions of the home are private spaces that spread into public space, and Linnet (2011), who suggests that the interrelation between sociality and interiority are essential in creating a cozy atmosphere. Such environments protect but also partially expose the intimacy of individuals (Aubert-Gamet and Cova 1999).

Our findings also reveal that the experience of being attached to a commercial place not always emerges through spectacular experiences. The development of place attachment does not require the delivery of extraordinary meanings, such as in the case of the Gettysburg battlefield (Chronis and Hampton 2008); nor does it require extraordinary settings or environments, such as in ESPNZone (Kozinets et al. 2004). It can be simply attained by experiencing the ordinariness of domestic life in a commercial setting, such as going to the kitchen to refill one's plate or finding one's way around a store with ease.

While our empirical context is urban France, the framework we identify can be applied to other settings. The literature suggests that familiarity, authenticity, and security as identified here in treasured commercial places have also emerged, albeit in discrete studies, in social science research on residential settings. For instance, social scientists suggest that home is the most familiar place, as it is known "from attic to cellar" (Korosec-Serfaty 1984, 303). Home is also an authentic place as it reflects inhabitants' selves (Cooper Marcus 1995). Finally, it is described as the ultimate shelter and safe haven (Bachelard 1964; Tuan 1977), emphasizing

Please use DOI when citing. Page numbers are not final. 
the security that it provides to its inhabitants (Scannell and Gifford 2010a). In their account of person, place, and process aspects of place attachment, Scannell and Gifford (2010a), also identify continuity as a determinant of place attachment. While not elaborated here, aspects of continuity also emerged in our study. Future studies could investigate how place disruption and discontinuity affect commercial place attachment in different settings.

Finally, while our study reveals a gift economy between customers, proprietors, and invitees, our participants do not identify as a community as in, for example, the research by Kozinets (2002). While there are incidents of sharing (Belk 2010), the participant narratives do not show markers of a community, even in the case of L'Abondance. Our participants indicate that they have similar aesthetic values as the other customers, but they otherwise remain unconnected. Interpersonal relationships are reinforced and generate constituencies of consumers. These are neither dyadic bonds between the consumer and the place, nor communities in the sociological sense that operate on generalized relations and reciprocations. Rather, the place serves as a gravity pull for small groups of highly loyal consumers who share reverence for the same object, place, or brand and engage in a chain of tripartite gift giving: from proprietor to the focal consumer, to the invitee, and back to the proprietor. Thus, the question remains whether these situated social relationships and gift exchanges establish community bonds, and on the nature of these bonds. Relatedly, the distinction between communal and collective versus shared places deserves more attention.

\section{Place Attachment as a Tripartite Exchange}

In contrast to prior research on consumer-place bonding (e.g., Maclaran and Brown 2005; Rosenbaum et al. 2007), we not only focus on the benefits that consumers derive from patronizing a place but also on how they reciprocate for what they receive. In doing so, we embrace a social exchange perspective on consumer-place interactions. Furthermore, we provide a nuanced account on how commercial exchanges are not limited to dyads but are embedded in social networks. As we have demonstrated, commercial place attachment is based on an exchange process between the place owner, the focal consumer, and the consumer's invitees. While demonstrating how place attachment develops through this exchange process, our work uncovers a tacit gift exchange that marks the ways ambassadorship perpetuates and extends place attachment between network actors. This gift exchange goes beyond what marketplace norms dictate for conventional service encounters and incorporates acts of reciprocity that go beyond marketplace transactions. As such, place attachment is driven by the consumers' participation in and contribution to an exchange process that is only partly market based. Through volunteering, over-reciprocating, and ambassadorship, our participants transcend their market relationships into the domestic realm. Ambassadorship further expands this domestic relationship by inviting third parties into the gift network.
The invitees play a specific role that prior research has ignored (Eiglier and Langeard 2000). While our data focus on the experiences of focal consumers rather than those of their invitees, the retrospections of focal consumers provide some insight into how they themselves were first introduced to their favorite places as invitees. They are not bystanders (Grönroos 2006; Lovelock 1983), or anonymous purchase pals that provide help or advice to others (McGrath and Otnes 1995), nor market mavens initiating discussion or answering consumers' requests without having a specific product expertise (Feick and Price 1987). Rather, they are an integral part of the place attachment experience itself as they become absorbed in the gift exchange. Some limited data collected from proprietors in the course of this study suggest that they also perceive themselves part of a gift economy. However, as our interpretation is predominantly based on the focal consumers' accounts, the issue of how the proprietors and third-party invitees experience the gift they receive from the attached customer remains underspecified.

Further investigation on the roles and experiences of the other parties of this tripartite exchange is therefore needed and should consider the extent to which these parties are aware of the exchange or whether the value exchange processes are better described as "value circulation" (Graeber 2001, 81). Indeed, such investigation might fruitfully adopt a wider anthropological perspective (Graeber 2001) on the theory of value to further our understanding of the exchange processes underlying and sustaining place attachment. As pointed by Sahlins (1972), third actors are often missing in discussions about exchange despite his assertions that the benefit (or added value) of a gift flourishes through circulation and through multiple actors. In this article, we introduce the role of the third actor, the invitee, to consumer gift systems and call for research on exchanges that take place in networks and constituencies that are neither dyadic nor fully formed communities or rhizomatic systems.

\section{Beyond Word of Mouth to Active Ambassadorship}

We find that ambassadorship behavior hinges on two gifts: a gift of invitation from the focal consumer to the invitee, and an act of reciprocation toward the proprietor. Ambassadorship is enacted through a ceremony of bringing a selected close contact to the treasured setting, which transforms the place from a commodity into a gift (Belk 2010). Because they love and respect the place, ambassadors want, as gatekeepers, to control the access to it; and, as guardians, the ways it is consumed. This gatekeeping tendency marks the difference between ambassadorship behavior and brand proselytism identified in prior studies. Studies on brand communities show that consumers can proselytize or evangelize the brand to people outside the brand community (Belk and Tumbat 2005; Schouten and McAlexander 1995) or demonstrate missionary work and devotion (Pimentel and Reynolds 2004). Contrary to these cases where the brand is proselytized to the mass of nonmembers of the community,

Please use DOI when citing. Page numbers are not final. 
ambassadorship is directed to specific people. As such, ambassadorship is a way of transmitting access to an exclusive network of consumers. It is a form of generalized reciprocity by "not directly rewarding their benefactors, but by benefiting other actors implicated in a social exchange situation" (Wade-Benzoni 2002, 1014).

Attached consumers are selective because they do not want their ambassadorship to result in alterations to the place's meanings. Additionally, they take an active role in recruiting by coconsuming the place with the invitees. This differentiates them from devotees whose recruiting behaviors are restricted to passive recommendations of word of mouth (Pimentel and Reynolds 2004). Ambassadorship constitutes an extreme form of engagement and contributes to the continuity of the commercial place. Further research should examine how ambassadorship perpetuates a lineage of consumers and contributes to the continuity of a commercial establishment.

To conclude, attachment to commercial settings has been neglected in consumer research as well as in the wider literature on place attachment. We show that place attachment emerges when a place instills domestic meanings supported by embedded social interactions. Attached consumers in turn help sustain and cocreate the setting through their support as volunteers and place ambassadors, who rely on invitees to perpetuate their bond and reciprocate the gift of homeyness given by the place and its proprietors. Understanding these actors, as gift-givers, thus highlights a tripartite anthropological perspective of social exchange within mundane commercial places.

\section{DATA COLLECTION INFORMATION}

The first author conducted all of the fieldwork, with the assistance of one colleague for the two phone interviews. The data were collected in three stages: from autumn of 2004 to spring 2005 (stage 1: in-depth interviews and retrospective essays), from winter of 2005 to spring of 2006 (stage 2: semistructured interviews), and finally from winter of 2009 to summer 2010 (stage 3: semistructured interviews of L'Abondance customers). All the interviews were conducted in French and analyzed by the first author. Based on translations proofread by a bilingual researcher, further interpretation of the data was discussed by the three authors on repeated iterations throughout the research project.

\section{REFERENCES}

Altman, Irwin, and Setha M. Low (1992), Place Attachment, New York: Plenum.

$\rightarrow$ Arnould, Eric J., and Linda L. Price (1993), "River Magic: Extraordinary Experience and the Extended Service Encounter," Journal of Consumer Research, 20 (June), 24-45.

Aubert-Gamet, Véronique, and Bernard Cova (1999), "Servicescapes: From Modern Non-Places to Postmodern Common Places," Journal of Business Research, 44 (1), 37-45.

Augé, Marc (1995), Non-lieux: Introduction à une anthropologie de la surmodernité, Paris: Seuil.

Bachelard, Gaston (1964), La poétique de l'espace, Paris: PUF.
Bardhi, Fleura, and Eric Arnould (2006), "An Examination of the Concept of Postmodern Home and the Role of Consumption in Home-Making Practices," Advances in Consumer Research, 33 (1), 651-54.

$\rightarrow$ Bardhi, Fleura, and Giana M. Eckhardt (2012), "Access Based Consumption: The Case of Car Sharing," Journal of Consumer Research, 39 (December), 881-98.

$\rightarrow$ Bardhi, Fleura, Giana M. Eckhardt, and Eric J. Arnould (2012), "Liquid Relationship to Possessions," Journal of Consumer Research, 39 (October), 510-29.

Belk, Russell W. (1979), "Gift-Giving Behavior," in Research in Marketing, Vol. 2, ed. Jagdish Sheth, Greenwich, CT: JAI Press, 95-126.

$\rightarrow$ _ (2010), "Sharing," Journal of Consumer Research, 36 (February), 715-34.

$\rightarrow$ Belk, Russell W., and Gülnur Tumbat (2005), "The Cult of Macintosh," Consumption, Markets and Culture, 8 (3), 205-17.

Berelson, Bernard R. (1952), Content Analysis in Communication Research, New York: Hafner.

$\rightarrow$ Beverland, Michael B., and Francis J. Farrelly (2010), "The Quest for Authenticity in Consumption: Consumers' Purposive Choice of Authentic Cues to Shape Experienced Outcomes," Journal of Consumer Research, 36 (February), 838-56.

$\rightarrow$ Bildtgård, Torbjörn (2010), "What It Means to 'Eat Well' in France and Sweden," Food and Foodways: Explorations in the History and Culture of Human Nourishment, 18 (4), 209-32.

Boltanski, Luc, and Laurent Thévenot (2006), On Justification: Economies of Worth, Princeton Studies in Cultural Sociology, trans. C. Porter, Princeton, NJ: Princeton University Press.

$\rightarrow$ Borghini, Stefania, Nina Diamond, Robert V. Kozinets, Mary Ann McGrath, Albert M. Muñiz Jr., and John F. Sherry Jr. (2009), "Why Are Themed Brandstores So Powerful? Retail Brand Ideology at American Girl Place," Journal of Retailing, 85 (3), 363-75.

$\rightarrow$ Brandenburg, Andrea M., and Matthew S. Carroll (1995), "Your Place or Mine? The Effect of Place Creation on Environmental Values and Landscape Meanings," Society and Natural Resources: An International Journal, 8 (5), 381-98.

$\rightarrow$ Brown, Barbara B., Douglas D. Perkins, and Graham Brown (2003), "Place Attachment in a Revitalizing Neighborhood: Individual and Block Levels of Analysis," Journal of Environmental Psychology, 23 (3), 259-71.

Carù, Antonella, and Bernard Cova (2007), "Consumer Immersion in an Experiential Context," in Consuming Experiences, ed. Antonella Carù and Bernard Cova, London: Routledge, 3245 .

$\rightarrow$ Celsi, Richard L., Randall L. Rose, and Thomas W. Leigh (1993), "An Exploration of High-Risk Leisure Consumption through Skydiving," Journal of Consumer Research, 20 (June), 1-23.

$\rightarrow$ Charleston, Stephanie (2009), "The English Football Ground as a Representation of Home," Journal of Environmental Psychology, 29 (1), 144-50.

$\rightarrow$ Chen, Yu (2009), "Possession and Access: Consumer Desires and Value Perceptions regarding Contemporary Art Collection and Exhibit Visits," Journal of Consumer Research, 35 (April), 925-40.

$\rightarrow$ Chronis, Athinodoros, and Ronald D. Hampton (2008), "Consuming the Authentic Gettysburg: How a Tourist Landscape Becomes an Authentic Experience," Journal of Consumer Behaviour, 7 (March-April), 111-26.

Cooper Marcus, Clare (2006), House as a Mirror of Self: Exploring the Deeper Meaning of Home, Lake Worth, FL: Nicolas-Hays.

Cova, Véronique, and Eric Rémy (2007), "I Feel Good—Who Needs

Please use DOI when citing. Page numbers are not final. 
the Market? Struggling and Having Fun with Consumer-Driven Experiences," in Consuming Experiences, ed. Antonella Carù and Bernard Cova, London: Routledge, 47-60.

$\rightarrow$ Cuba, Lee, and David M. Hummon (1993), "A Place to Call Home: Identification with Dwelling, Community and Region," Sociological Quarterly, 34 (1), 111-31.

Danesi, Giada (2012), "Pleasures and Stress of Eating Alone and Eating Together among French and German Young Adults," Journal of Eating and Hospitality Research, 1, 77-91.

$\rightarrow$ Devine-Wright, Patrick, and Yuko Howes (2010), "Disruption to Place Attachment and the Protection of Restorative Environments: A Wind Energy Case Study," Journal of Environmental Psychology, 30 (3), 271-80.

Eiglier, Pierre, and Eric Langeard (2000), Servuction: Le marketing des services, Paris: Dunod.

$\rightarrow$ Feick, Lawrence F., and Linda L. Price (1987), "The Market Maven: A Diffuser of Marketplace Information," Journal of Marketing, 51 (January), 83-97.

$\rightarrow$ Filser, Marc, and Gilles Paché (2008), "La dynamique des canaux de distribution: Approches théoriques et ruptures stratégiques," Revue Française de Gestion, 182 (2), 109-34.

France 2 (2011), "La gastronomie du micro-onde," Envoyé Spécial, television broadcast on June 30 .

Fried, Marc (1963), "Grieving for a Lost Home," in The Urban Condition: People and Policy in the Metropolis, ed. Leonard J. Duhl, New York: Basic Books, 151-71.

$\rightarrow$ - (2000), "Continuities and Discontinuities of Place," Journal of Environmental Psychology, 20 (3), 193-205.

$\rightarrow$ Giesler, Markus (2006), "Consumer Gift Systems," Journal of Consumer Research, 33 (September), 283-90.

Giuliani, Maria Vittoria (2003), "Theories of Attachment and Place Attachment," in Psychological Theories for Environmental Issues, ed. Mirilia Bonnes, Terence Lee, and Marino Bonaiuto, Hants: Ashgate, 137-70.

Graeber, David (2001), Toward an Anthropological Theory of Value, New York: Palgrave.

$\rightarrow$ Grayson, Kent, and Radan Martinec (2004), "Consumer Perceptions of Iconicity and Indexicality and Their Influence on Assessments of Authentic Market Offerings," Journal of Consumer Research, 31 (September), 296-312.

$\rightarrow$ Grönroos, Christian (2006), "Adopting a Service Logic for Marketing," Marketing Theory, 6 (3), 317-33.

$\rightarrow$ Guest, Avery M., and Barrett A. Lee (1983), "Sentiment and Evaluation as Ecological Variables," Sociological Perspectives, 26 (2), 159-84.

$\rightarrow$ Halpenny, Elizabeth A. (2010), "Pro-Environmental Behaviours and Park Visitors: The Effect of Place Attachment," Journal of Environmental Psychology, 30 (4), 409-21.

$\rightarrow$ Hidalgo, Maria Carmen, and Bernardo Hernandez (2001), "Place Attachment: Conceptual and Empirical Questions," Journal of Environmental Psychology, 21 (3), 273-81.

Holbrook, Morris B. (1998), "The Retailing of Performance and the Performance of Service: The Gift of Generosity with a Grin and the Magic of Munificence with Mirth," in Servicescapes: The Concept of Place in Contemporary Markets, ed. John F. Sherry, Lincolnwood, IL: NTC Business Books, 487-514.

$\rightarrow$ Hollenbeck Candice R., Cara Peters, and George M. Zinkhan (2008), "Retail Spectacles and Brand Meaning: Insights from a Brand Museum Case Study," Journal of Retailing, 84 (3), 334-53.

$\rightarrow$ Holt, Douglas B. (2002), "Why Do Brands Cause Trouble? A Dialectical Theory of Consumer Culture and Branding,"Journal of Consumer Research, 29 (June), 70-90.
IPSOS (2011), Survey Conducted for Inter-Loire, between the 29th of November and 7th of December, on a Sample of 100 Wine Bar Tenders in France, Paris: IPSOS.

$\rightarrow$ Jorgensen, Bradley S., and Richard C. Stedman (2006), “A Comparative Analysis of Predictors of Sense of Place Dimensions: Attachment to, Dependence on, and Identification with Lakeshore Properties," Journal of Environmental Management, 79 (3), 316-27.

$\rightarrow$ Joy, Annamma (2001), "Gift Giving in China and the Continuum of Social Ties," Journal of Consumer Research, 28 (September), 239-56

$\rightarrow$ Kelly, Gail, and Karin Hosking (2008), "Nonpermanent Residents, Place Attachment, and 'Sea Change' Communities," Environment and Behavior, 40 (4), 575-94.

$\rightarrow$ Korosec-Serfaty, Perla (1984), "The Home from Attic to Cellar," Journal of Environmental Psychology, 4 (4), 303-21.

$\rightarrow$ Kozinets, Robert V. (2002), "Can Consumers Escape the Market? Emancipatory Illuminations from Burning Man," Journal of Consumer Research, 29 (June), 20-38.

$\rightarrow$ Kozinets, Robert V., John F. Sherry Jr., Benet DeBarry-Spence, Adam Duhachek, Krittinee Nuttavuthisit, and Diana Storm (2002), "Themed Flagship Brandstores in the New Millennium: Theory, Practice, Prospects," Journal of Retailing, 78 (1), 17-29.

$\rightarrow$ _ - (2004), "Ludic Agency and Retail Spectacle," Journal of Consumer Research, 31 (December), 658-72.

$\rightarrow$ Kyle, Gerard T., James D. Absher, and Alan R. Graefe (2003), "The Moderating Role of Place Attachment on the Relationship between Attitudes toward Fees and Spending Preferences," Leisure Sciences, 25 (1), 33-50.

$\rightarrow$ Kyle, Gerard T., Alan R. Graefe, and Robert Manning (2005), "Testing the Dimensionality of Place Attachment in Recreational Settings," Environment and Behavior, 37 (2), 153-77.

$\rightarrow$ Kyle, Gerard T., Alan R. Graefe, Robert Manning, and James Bacon (2004), "Effects of Place Attachment on Users' Perceptions of Social and Environmental Conditions in a Natural Setting," Journal of Environmental Psychology, 24 (2), 213-25.

$\rightarrow$ Lewicka, Maria (2011a), "Place Attachment: How Far Have We Come in the Last 40 Years?" Journal of Environmental Psychology, 31 (3), 207-30.

$\rightarrow$ —_ (2011b), "On the Varieties of People's Relationships with Places: Hummon's Typology Revisited," Environment and Behavior, 43 (5), 676-709.

$\rightarrow$ Linnet, Jeppe Trolle (2011), "Money Can’t Buy Me Hygge: Danish Middle-Class Consumption, Egalitarianism, and the Sanctity of Inner Space," Social Analysis, 55 (2), 21-44.

$\rightarrow$ Lovelock, Christopher H. (1983), "Classifying Services to Gain Strategic Marketing Insights," Journal of Marketing, 47 (3), 9-20.

$\rightarrow$ Maclaran, Pauline, and Stephen Brown (2005), "The Center Cannot Hold: Consuming the Utopian Marketplace," Journal of Consumer Research, 32 (September), 311-23.

$\rightarrow$ McAlexander, James H., John W. Schouten, and Harold F. Koenig (2002), "Building Brand Community," Journal of Marketing, 66 (January), 38-54.

McCracken, Grant (1988), The Long Interview, Newbury Park, CA: Sage.

__ (1989), “'Homeyness,' a Cultural Account of One Constellation of Consumer Goods and Meanings," in Interpretive Consumer Research, ed. Elisabeth C. Hirschman, Provo, UT: Association for Consumer Research, 168-83.

$\rightarrow$ McGrath, Mary Ann, and Cele Otnes (1995), "Unacquainted In-

Please use DOI when citing. Page numbers are not final. 
fluencers: When Strangers Interact in the Retail Setting," Journal of Business Research, 32 (3), 261-72.

Malinowski, Bronislaw (1922), Argonauts of the Western Pacific, London: Routledge.

Mauss, Marcel (1925/1967), The Gift: Forms and Functions of Exchange in Archaic Societies, ed. Ian Cunnison, New York: Norton.

$\rightarrow$ Mazumdar, Shampa, and Sanjoy Mazumdar (1993), "Religion and Place Attachment: A Study of Sacred Places," Journal of Environmental Psychology, 24 (3), 385-97.

$\rightarrow$ Mesch, Gustavo S., and Orit Manor (1998), "Social Ties, Environmental Perception, and Local Attachment," Environment and Behavior, 30 (4), 504-19.

$\rightarrow$ Mehta, Raj, and Russell W. Belk (1991), "Artifacts, Identity, and Transition: Favorite Possessions of Indians and Indian Immigrants to the United States," Journal of Consumer Research, 17 (March), 398-411.

$\rightarrow$ Milligan, Melinda J. (1998), "Interactional Past and Potential: The Social Construction of Place Attachment," Symbolic Interaction, 21 (1), 1-33.

Noschis, Kaj (1984), Signification affective du quartier, Paris: Méridiens-Klincksieck.

$\rightarrow$ O'Guinn, Tom C., and Russell W. Belk (1989), "Heaven on Earth Consumption at Heritage Village, USA," Journal of Consumer Research, 16 (September), 227-38.

Oldenburg, Ray (1999), The Great Good Place: Cafés, Coffee Shops, Community Centers, Beauty Parlors, General Stores, Bars, Hangouts and How They Get You through the Day, New York: Paragon House.

Pimentel, Ronald W., and Christy E. Reynolds (2004), "A Model for Consumer Devotion: Affective Commitment with Proactive Sustaining Behaviors," Academy of Marketing Science Review 8 (7).

$\rightarrow$ Price, Linda L., and Eric J. Arnould (1999), "Commercial Friendships: Service Provider-Client Relationships in Context," Journal of Marketing, 63 (October), 38-56.

$\rightarrow$ Price, Linda L., Eric J. Arnould, and Carolyn Folkman Curasi (2000), "Older Consumers' Disposition of Special Possessions," Journal of Consumer Research, 27 (September), 179-201.

$\rightarrow$ Price, Linda L., Eric J. Arnould, and Patrick Tierney (1995), "Going to Extremes: Managing Service Encounters and Assessing Provider Performance," Journal of Marketing, 59 (2), 83-97.

$\rightarrow$ Proshansky, Harold, Abbe K. Fabian, and Robert Kaminoff (1983), "Place Identity: Physical World Socialization of the Self," Journal of Environmental Psychology, 3 (1), 57-83.

Relph, Edward C. (1976), Place and Placelessness, London: Pion.

Ritzer, George (1998), The McDonaldization Thesis: Explorations and Extensions, London: Sage.

$\rightarrow$ Rosenbaum, Mark S. (2006), "Exploring the Social Supportive Role of Third Places in Consumers' Lives," Journal of Service Research, 9 (1), 59-72.

$\rightarrow$ Rosenbaum, Mark S., James Ward, Beth A. Walker, and Amy L. Ostrom (2007), "A Cup of Coffee with a Dash of Love: An Investigation of Commercial Social Support and Third-Place Attachment," Journal of Service Research, 10 (1), 43-59.

Rubinstein, Robert L., and Pauline A. Parmelee (1992), "Attachment to Place and the Representation of the Life Course by the Elderly," in Place Attachment, ed. Irwin Altman and Setha M. Low, New York: Plenum, 139-61.

Sahlins, Marschall D. (1972), Stone Age Economics, Hawthorne, NY: Aldine de Gruyter.

Sandikci, Ozlem, and Douglas B. Holt (1998), "Mailing Society:
Mall Consumption Practices and the Future of Public Space," in Servicescapes: The Concept of Place in Contemporary Markets, ed. John F. Sherry Jr., Lincolnwood, IL: NTC Business Books, 305-36.

$\rightarrow$ Scannell, Leila, and Robert Gifford (2010a), "Defining Place Attachment: A Tripartite Organizing Framework," Journal of Environmental Psychology, 30 (1), 1-10.

$\rightarrow$ _ _ (2010b), "The Relations between Natural and Civic Place Attachment and Pro-Environmental Behavior," Journal of Environmental Psychology, 30 (3), 289-97.

$\rightarrow$ Schouten, John W., and James H. McAlexander (1995), "Subcultures of Consumption: An Ethnography of the New Bikers," Journal of Consumer Research, 22 (June), 43-61.

$\rightarrow$ Schwartz, Barry (1967), "The Social Psychology of the Gift," American Journal of Sociology, 73 (1), 1-11.

Shamai, Shmuel (1991), "Sense of Place: An Empirical Measurement," Geoforum, 22 (3), 347-58.

$\rightarrow$ Smith, Sandy G. (1994), "The Essential Qualities of a Home," Journal of Environmental Psychology, 14 (1), 31-46.

$\rightarrow$ Sherry, John F., Jr. (1983), "Gift Giving in Anthropological Perspective," Journal of Consumer Research, 10 (September), 157-68.

__ (1998), Servicescapes: The Concept of Place in Contemporary Markets, Lincolnwood, IL: NTC Business Books.

Sherry, John F., Jr., Robert V. Kozinets, and Stefania Borghini (2007), "Experiential Co-creation through Emplacement, Ritualization and Community," in Consuming Experiences, ed. Antonella Carù and Bernard Cova, London: Routledge, 1531 .

$\rightarrow$ Stedman, Richard C. (2002), "Toward a Social Psychology of Place: Predicting Behavior from Place-Based Cognitions, Attitude, and Identity," Environment and Behavior, 34 (5), 561-81.

$\rightarrow$ Tepper, Kelly (1994), "The Role of Labeling Processes in Elderly Consumers' Responses to Age Segmentation Cues," Journal of Consumer Research, 20 (March), 503-19.

$\rightarrow$ Theodori, Gene L. (2001), "Examining the Effects of Community Satisfaction and Attachment on Individual Well-Being," Rural Sociology, 66 (4), 618-28.

$\rightarrow$ Thompson, Craig J., and Zeynep Arsel (2004), "The Starbucks Brandscape and Consumers' (Anticorporate) Experiences of Glocalization," Journal of Consumer Research, 31 (December), 631-42.

$\rightarrow$ Thompson, Craig J., William B. Locander, and Howard R. Pollio (1989), "Putting Consumer Experience Back into Consumer Research: The Philosophy and Method of Existential-Phenomenology," Journal of Consumer Research, 16 (September), 133-46.

Tuan, Yi-Fu (1977), Space and Place: The Perspective of Experience, Minneapolis: University of Minnesota Press.

$\rightarrow$ Vorkinn, Marit, and Hanne Riese (2001), "Environmental Concern in a Local Context: The Significance of Place Attachment," Environment and Behavior, 33 (2), 249-63.

$\rightarrow$ Wade-Benzoni, Kimberly A. (2002), "A Golden Rule over Time: Reciprocity in Intergenerational Allocation Decisions," Academy of Management Review, 45 (5), 1011-28.

$\rightarrow$ Wakefield, Sarah E. L., Susan J. Elliot, Donald C. Cole, and John D. Eyles (2001), "Environmental Risk and (Re)Action: Air Quality, Health, and Civic Involvement in an Urban Industrial Neighborhood," Health and Place, 7 (3), 163-77.

$\rightarrow$ Weinberger, Michelle L., and Melanie Wallendorf (2012), "Intracommunity Gifting at the Intersection of Contemporary Moral

Please use DOI when citing. Page numbers are not final. 
and Market Economies," Journal of Consumer Research, 39 (June), 74-92.

Williams, Daniel R., Cary D. McDonald, Carla M. Riden, and Musaffer Usyal (1995), "Community Attachment, Regional Identity, and Resident Attitudes toward Tourism," in Proceedings of the 26th Annual Travel and Tourism Research, Wheat Ridge, CO: Trail and Tourism Research Association, 424-28.

$\rightarrow$ Williams, Daniel R., Michael E. Patterson, Joseph W. Roggenbuck, and Alan E. Watson (1992), "Beyond the Commodity Metaphor: Examining Emotional and Symbolic Attachment to Place," Leisure Sciences, 14 (1), 29-46.

Zaichkowsky, Judith Lynne (1985), "Familiarity: Product Use, Involvement, or Expertise?" in Advances in Consumer Research, Vol. 12, ed. Elizabeth C. Hirschman and Morris B. Holbrook, Provo, UT: Association for Consumer Research, 296-99.

Please use DOI when citing. Page numbers are not final. 